RESEARCH ARTICLE

\title{
Effect of Sulphur on Yield and Biochemical Constituents in Groundnut (Arachis hypogaea L.) grown on Vertic Ustropept of Tamil Nadu
}

\author{
Elakiya $\mathbf{N}^{\star 1}$, Meena $\mathbf{S}^{1}$ and Amirtham $\mathrm{D}^{2}$ \\ ${ }^{* 1}$ Department of Soil Science and Agricultural Chemistry, Tamil Nadu Agricultural University, Coimbatore - 641003. \\ ${ }^{2}$ Department of Food Process Engineering, AEC \& RI, TNAU, Coimbatore - 641003.
}

Received : $08^{\text {th }}$ January, 2020

Revised : $10^{\text {th }}$ February, 2020

Accepted : $25^{\text {th }}$ February, 2020

\begin{abstract}
A pot culture experiment was conducted with groundnut ( $\mathrm{CO} 7$ ) in a sulphur deficient (7.19 $\mathrm{mg} \mathrm{kg}^{-1}$ ) Inceptisol (Vertic Ustropept) at the Radioisotope (Tracer) Laboratory, Department of Soil Science and Agricultural Chemistry, Tamil Nadu Agricultural University, Coimbatore during October 2016 to January 2017. The treatment structure comprised five levels of sulphur $\left(0,20,40,60\right.$, and $\left.80 \mathrm{~kg} \mathrm{ha}^{-1}\right)$ along with the recommended fertilizer dose. The variation in yield and the changes in starch, sugars, cysteine, methionine, protein, and oil content with kernel development as influenced by the sulphur application were studied. The yield attributes viz., number of pods pot $^{-1}$, pod and kernel yield pot ${ }^{-1}$ and shelling percentage, were remarkably influenced due to the application of sulphur up to $60 \mathrm{~kg} \mathrm{ha}^{-1}$, which was comparable with S @ $40 \mathrm{~kg} \mathrm{ha}^{-1}$ and had an adverse effect with S @ 80 kg ha $^{-1}$. In all the stages of sampling (30 DAS, 15 DOP (75 DAS), 30 DOP (90 DAS) and at harvest stage), starch, total sugars, reducing and non-reducing sugars of groundnut were found to decrease with increasing $S$ levels with control recording the highest value and $\mathrm{S} @ 60 \mathrm{~kg} \mathrm{ha}^{-1}$ recording the lowest value. During crop growth, protein content and sulphur-containing amino acids viz., cysteine, and methionine showed an increasing trend up to 60 kg S ha-1 application and recorded comparable values with S @ 40 kg ha-1. Similarly, oil content in the kernel steadily increased with stages of kernel development. The highest oil content at all stages of kernel development

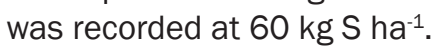

Keywords: Sulphur, groundnut, yield, starch, sugars, cysteine, methionine

\section{INTRODUCTION}

Groundnut (Arachis hypogaea L.), the king of oilseed crops, is the third most important oilseed crop of the world cultivated widely in 96 countries (Upadhaya et al., 2003). Though the share of groundnut to the total oilseed production in India has been falling since 1950, from 70 per cent to the present level of 33 per cent, groundnut is still the major oilseed crop in India which accounts for about 27 per cent of the global area and contributes 19 per cent to world groundnut production (Rai et al., 2016). Tamil Nadu ranks fourth in terms of groundnut area (4.419 lakh ha) and third in production (9.737 lakh tonnes, Singh, 2014).

Sulphur, the fourth major plant nutrient after nitrogen, phosphorus, and potassium, is indispensable for the appropriate plant growth and development (Anjum et al., 2012). Sulphur is inevitable for oilseed crops as it is involved in the synthesis of essential amino acids and is a vital component of coenzymes involved in oil synthesis (Chaudhary, 2009). Sulphur has been reported to influence the productivity of oilseed crops and total oil content considerably (Jankowski et al., 2008; Egesel et al., 2009). It is rightly called as the master nutrient of all oilseed crops as each unit of fertilizer sulphur generates 3-5 units of edible oil (Ramdevputra et al., 2010). Their sulphur requirement for proper growth and yield is more than that of many other crops (Fahmina et al., 2013).

Areas of sulphur deficiency are becoming widespread throughout the world due to the use of high-analysis fertilizers with low $\mathrm{S}$ returns with farmyard manure, high yielding varieties, and intensive agriculture, declining use of sulphur -containing fungicides, and reduced atmospheric inputs caused by stringent emission regulations (Tandon, 1995; CeCeotti, 1996; Randhawa and Arora, 2000; Nader and Nadia, 2011). As the intensity of cropping is gradually increasing, the response of oilseeds to sulphur is also increasing 
(Ghosh et al., 2002) and the variable response of groundnut to sulphur has been reported by many workers (Kumar et al., 2008; Ramdevputra et al., 2010; Giri et al., 2011). Hence, this investigation was attempted to study the importance of sulphur in realizing yield and quality of groundnut crop and to study the role of sulphur in influencing the biochemical constituents of groundnut.

\section{MATERIAL AND METHODS}

\section{Experimental description}

A pot culture experiment was conducted at the Radioisotope Laboratory, Department of Soil Science and Agricultural Chemistry, Tamil Nadu Agricultural University, Coimbatore during October 2016 and January 2017. The experimental soil was sandy loam in texture, non-calcareous, and taxonomically classified as an Inceptisol (Vertic Ustropept) and was slightly alkaline in soil reaction ( $\mathrm{pH} 7.63)$, non-saline (EC $0.18 \mathrm{dS} \mathrm{m}^{-1}$ ) with CEC of $13.09 \mathrm{cmol}(p+) \mathrm{kg}^{-1}$. The soil was medium in available nitrogen $(300 \mathrm{~kg}$ ha-1), phosphorus (15.5 kg ha-1), and high in available potassium (526 kg ha-1) with an organic carbon content of $4.70 \mathrm{~g} \mathrm{~kg}^{-1}$. The available sulphur status of the soil was deficient $\left(7.19 \mathrm{mg} \mathrm{kg}^{-1}\right)$. The soil was sufficient with respect to available micronutrients like Zn, Fe, Mn, and Cu 2.57, 21.20, 8.80, and 2.15 $\mathrm{mg} \mathrm{kg}^{-1}$, respectively. The soil was non-calcareous in nature with the calcium carbonate content of 4.30 per cent.

The groundnut variety CO 7 obtained from Department of Oilseeds, Centre for Plant Breeding and Genetics, TNAU was used in this study. Nutrients were applied to the pots on a soil weight basis. All the pots received uniform application of nitrogen @ $25 \mathrm{~kg} \mathrm{ha}^{-1}$, phosphorus @ $50 \mathrm{~kg} \mathrm{ha}^{-1}$, and potassium @ 75 kg ha-1, which were applied through urea, diammonium phosphate, and muriate of potash (Crop Production Guide, 2012). Sulphur was applied basally @ 0, 20, 40, 60 and $80 \mathrm{~kg} \mathrm{ha}^{-1}$ in the form of elemental sulphur along with Thiobacillus at 21 days before sowing. The crop was harvested at 105 days after sowing, and the yield was recorded.

\section{Collection of samples}

Plant samples were collected from the pots at vegetative (30 DAS), 15 days of podding (DOP) (75 DAS), 30 DOP (90 DAS), and at harvest stage. At 15 DOP, 30 DOP, and at maturity (45 DOP), kernels were separated from the plant for biochemical analysis (total sugars, reducing sugars, starch, cysteine, methionine, and protein) which was carried out in the fresh samples. The plants were uprooted at vegetative (30 DAS), 15 DOP, 30 DOP, and at harvest and separated into shoot and pod samples. The pod samples after using for biochemical analysis were oven-dried, and the yield was recorded.
Total sugars and starch was estimated by the Anthrone method (Hodge and Hoferiter, 1962), and reducing sugars by Nelson-Somogyi Method (Somogyi, 1952). Non reducing sugar content of the sample was computed by taking the difference between total sugars and reducing sugars. Protein content was estimated by Lowry's method (Lowry et al., 1951). Cysteine and methionine were estimated by spectrophotometric method (Gaitonde, 1967; Horn et al., 1946). The oil content in the samples was estimated by the method of A.O.A.C. (1960).

\section{Statistical analysis}

The experimental data were statistically analyzed as suggested by Gomez and Gomez (1984). For significant results, the critical difference was worked out at 5 per cent level.

\section{RESULTS AND DISCUSSION}

\section{Effect of sulphur levels on yield parameters and yield of groundnut}

\section{Pod yield}

A significant variation in pod yield was recorded due to the application of sulphur (Table 1). The highest pod yield of $23.42 \mathrm{~g} \mathrm{pot}^{-1}$ was recorded by S@ $60 \mathrm{~kg} \mathrm{ha}^{-1}$ and was comparable with S@ 40 kg $\mathrm{ha}^{-1}\left(21.95 \mathrm{~g} \mathrm{pot}^{-1}\right)$. The increase in pod yield was 54.69 and 44.98 per cent over control for the addition of S@60 and 40 kg ha-1, respectively.
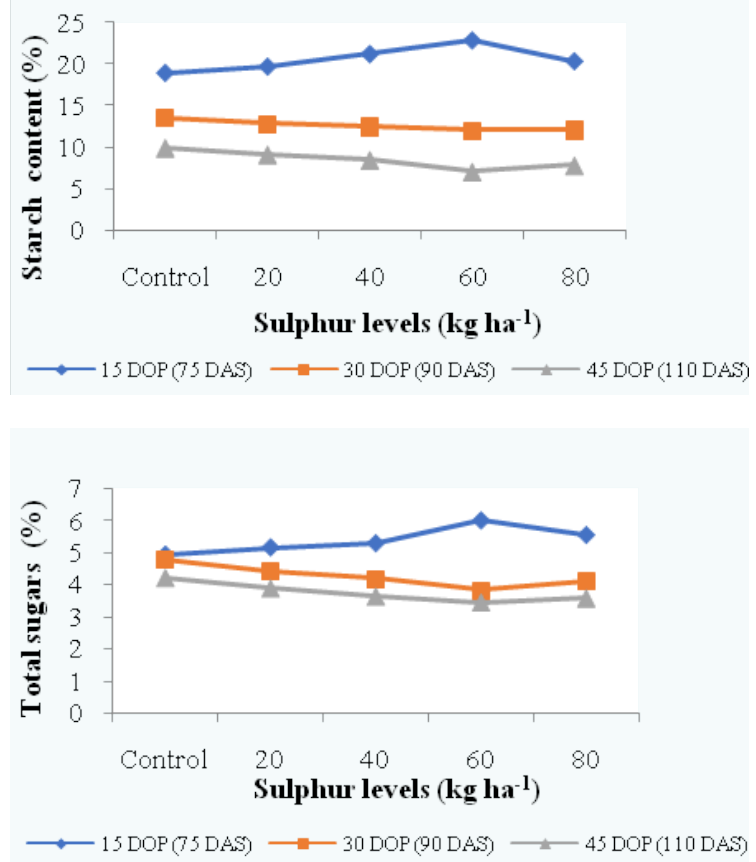

Figure 1. Effect of sulphur levels on starch and total sugars at different stages of kernel development in groundnut (var.CO 7)

Yield enhancement in groundnut with the addition of sulphur has been reported by many workers (Giri 
et al., 2011; Dutta et al., 2015; Saha et al., 2015); Response to the increasing level of sulphur might be ascribed to an adequate supply of nutrients resulted in high production of photosynthates and their translocation to sink (Tomer et al., 1997; Patel et al., 2009).

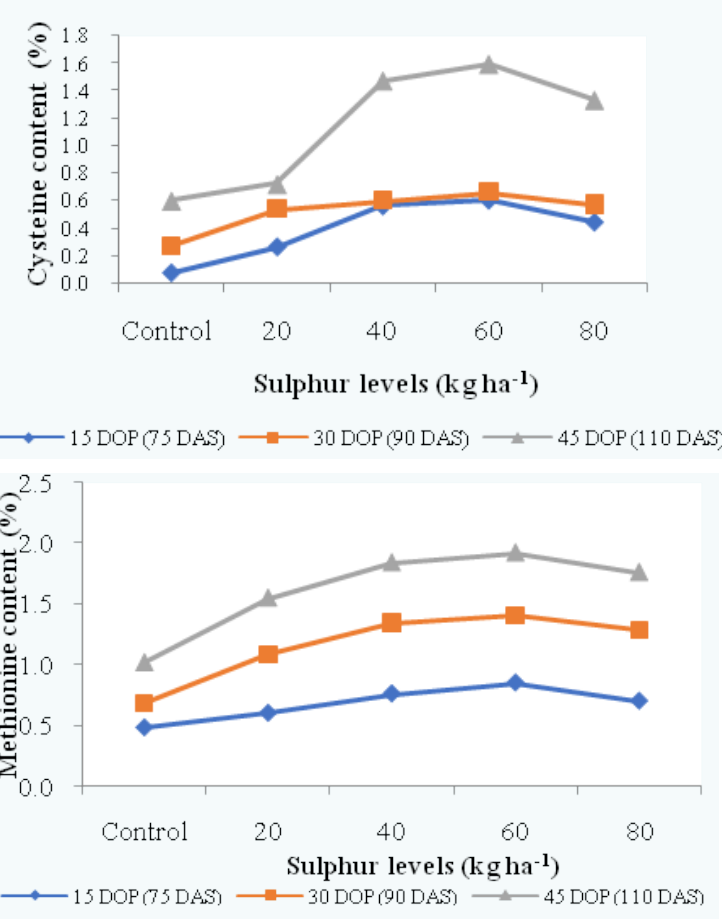

Figure 2. Effect of sulphur levels on cysteine and methionine at different stages of kernel development in groundnut (var.CO 7)

\section{Kernel yield}

The differential impact of treatments was quite clear on the kernel yield of groundnut and the highest kernel yield of $16.90 \mathrm{~g} \mathrm{pot}^{-1}$ (Table 1) was recorded by the addition of $\mathrm{S}$ at $60 \mathrm{~kg} \mathrm{ha}^{-1}$.

Enhancing the dose of sulphur beyond $60 \mathrm{~kg} \mathrm{ha}^{-1}$ did not produce any significant advantage rather than a decrease in seed yield. The higher dose of sulphur fertilizer beyond $80 \mathrm{~kg} \mathrm{ha}^{-1}$ decreased the seed yield considerably, and the negative response to higher sulphur might be due to the imbalance and toxic effect caused by increasing sulphur level. This result showed that pod yield of groundnut was increased with the increase in sulphur application up to a certain limit, and similar results were reported in groundnut (Dutta et al., 2015) and sunflower (Nasreen and Huq, 2002).

\section{Shelling percentage}

Imposed sulphur treatments had a significant influence on shelling percentage, which varied between 65.12 to 72.18 per cent (Table 1). The addition of S@60 kg ha-1 recorded significantly higher shelling percentage (72.18) and was found to be on par with 40 and $80 \mathrm{~kg} \mathrm{~S} \mathrm{ha}^{-1}$.
The increase in shelling percentage due to 60 kg S ha-1 was 10.84 per cent over control, and a similar increase in shelling percentage with sulphur application was reported by Singh and Singh (2016).

\section{Starch}

In the early stages of kernel development, sulphur application had a profound influence on starch content. Sulphur @ 60 kg ha-1 recorded significantly higher starch content (22.83\%). With development, the mean starch content decreased from 12.64 per cent at 30 DOP (90 DAS) to 8.45 per cent at maturity (Figure 1). Sulphur applied @ $60 \mathrm{~kg} \mathrm{ha}^{-1}$ recorded the lowest starch content at 30 and 45 DOP (at maturity).
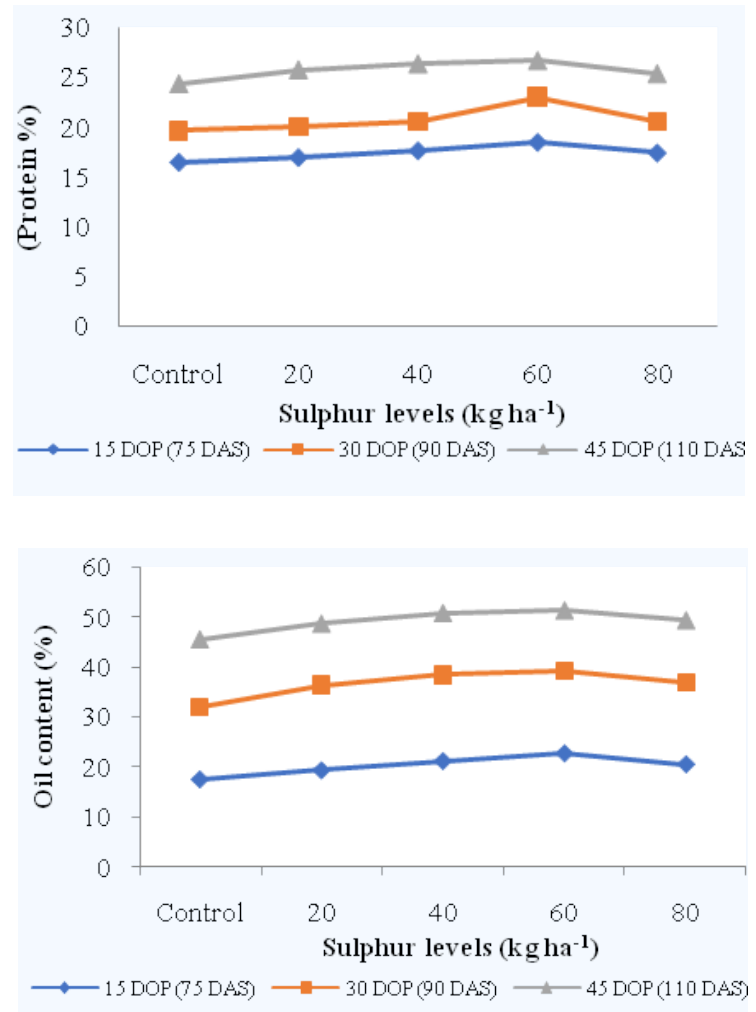

Figure 3. Effect of sulphur levels on protein and oil content at different stages of kernel development in groundnut (var.CO 7)

Starch may serve as a temporary reservoir of energy to be made available during the period of maximum oil synthesis (15 to $30 \mathrm{DOP}$ ) by its conversion to glucose and consequently providing various precursors for fatty acid synthesis. A decrease in starch content with the advancement in the kernel development stage was also reported by Sukhija et al., (1987) in groundnut.

Application of sulphur affected adversely the starch content, which might be due to increased conversion of starch to oil in the grain of oil crops with increasing addition of sulphur. Starch is broken to produce glucose - 1 phosphate, which ultimately enters the glycolytic pathway, resulting in the

$107|1-3| 76$ 
formation of acetyl Co A. Sulphur being an essential component of enzymes helps in bringing about a higher turnover of starch to oil and protein leaving behind less starch in the grain. This confirms the findings of Yadav and Singh (1970).

\section{Total, reducing and non reducing sugars}

Total sugars varied from 4.94 per cent (control) to 5.92 per cent (S@ $60 \mathrm{~kg} \mathrm{ha}^{-1}$ ) at 15 DOP (Table 2 \& Figure 1). The variation was between 3.97 (S@ 60 $\mathrm{kg} \mathrm{ha}^{-1}$ ) to 4.58 (control) per cent at $30 \mathrm{DOP}$ and from
3.36 to 4.31 per cent at maturity. At all stages of sampling, S@80 kg ha-1 and S@ 40 kg ha-1 recorded comparable values. Sulphur applied treatments recorded lower reducing sugar content at 15 DOP, 30 DOP, and 45 DOP than control. At maturity, the lowest value was recorded by S@ 60 kg ha-1 $(0.201$ $\%)$ and was comparable with S@40 kg ha-1 $(0.228 \%)$. Non reducing sugar content followed the same trend as that of reducing sugars and showed a reducing trend from 4.82 per cent to 3.49 per cent.

Table 1. Effect of sulphur levels on a number of pods, pod yield, kernel yield and shelling percentage in groundnut (var. CO 7)

\begin{tabular}{|c|c|c|c|}
\hline Treatments & Pod yield $\left(\mathrm{g} \mathrm{pot}^{-1}\right)$ & Kernel yield $\left(\mathrm{g} \mathrm{pot}^{-1}\right)$ & Shelling percentage \\
\hline Control (NPK alone) & 15.14 & 9.86 & 65.12 \\
\hline S @ 20 kg ha-1 & 19.34 & 13.04 & 67.42 \\
\hline s @ 40 kg ha-1 & 21.95 & 15.77 & 71.86 \\
\hline S @ 60 kg ha-1 & 23.42 & 16.90 & 72.18 \\
\hline S @ 80 kg ha-1 & 20.24 & 14.35 & 70.89 \\
\hline Mean & 20.02 & 13.98 & 69.49 \\
\hline $\mathrm{SE}_{\mathrm{d}}$ & 0.90 & 0.16 & 1.25 \\
\hline$C D(P=0.05)$ & 1.91 & 0.34 & 2.67 \\
\hline
\end{tabular}

An increase in the total, reducing and non reducing sugars with sulphur fertilization was observed in the early stage of kernel development (15 DOP). Fazli et al., (2010) reported a significant increase in the total, reducing and non reducing sugar content of seeds at an early stage of development. The decrease in reducing, non reducing, and total sugars in sulphur applied treatments was observed at 30 DOP (75 DAS) and 45 DOP (105 DAS). This is in line with the findings of Sukhija et al., (1987) in groundnut.

Table 2. Effect of sulphur levels on total sugar, reducing sugars and non-reducing sugars in groundnut (var. CO 7)

\begin{tabular}{lrrrrrrrrr}
\hline \multirow{2}{*}{ Treatments } & \multicolumn{3}{c}{ Total sugar (\%) } & \multicolumn{3}{c}{ Reducing sugars (\%) } & \multicolumn{3}{c}{ Non-reducing sugars (\%) } \\
\cline { 2 - 10 } & 15 DOP & 30 DOP & 45 DOP & 15 DOP & 30 DOP & 45 DOP & 15 DOP & 30 DOP & 45 DOP \\
\hline Control & 4.94 & 4.58 & 4.31 & 0.512 & 0.456 & 0.384 & 4.43 & 4.12 & 3.93 \\
S@20 kg ha ${ }^{-1}$ & 5.15 & 4.43 & 3.98 & 0.549 & 0.424 & 0.359 & 4.60 & 4.01 & 3.62 \\
S@40 kg ha ${ }^{-1}$ & 5.65 & 4.09 & 3.68 & 0.601 & 0.383 & 0.228 & 5.05 & 3.71 & 3.45 \\
$\mathrm{~S} @ 60 \mathrm{~kg} \mathrm{ha}^{-1}$ & 5.92 & 3.97 & 3.36 & 0.626 & 0.352 & 0.201 & 5.29 & 3.62 & 3.23 \\
$\mathrm{~S} @ 80 \mathrm{~kg} \mathrm{ha}^{-1}$ & 5.31 & 4.23 & 3.56 & 0.570 & 0.404 & 0.252 & 4.74 & 3.83 & 3.31 \\
Mean & 5.39 & 4.26 & 3.78 & 0.572 & 0.404 & 0.285 & 4.82 & 3.86 & 3.49 \\
$\mathrm{SE}$ & 0.21 & 0.16 & 0.12 & 0.014 & 0.012 & 0.013 & 0.10 & 0.09 & 0.13 \\
$\mathrm{CD}(\mathrm{P}=0.05)$ & 0.44 & 0.34 & 0.26 & 0.029 & 0.026 & 0.026 & 0.22 & 0.21 & 0.28 \\
\hline
\end{tabular}

\section{Cysteine and methionine content}

Sulphur application had a profound influence on cysteine and methionine content (Figure 2). Sulphur @ $60 \mathrm{~kg} \mathrm{ha}^{-1}$ registered the highest cysteine content of 0.60 (15 DOP), 0.66 (30 DOP), and 1.59 per cent at maturity and was on par with sulphur @ $40 \mathrm{~kg} \mathrm{ha}^{-1}$ at all stages of kernel development (Table 5). Sulphur applied @ 60 kg ha-1 recorded the highest methionine content of $0.85,1.40$ and 1.92 per cent at 15 DOP (75 DAS), 30 DOP (90 DAS) and at 45 DOP (maturity) respectively (Figure 2). Though at 15 DOP (75 DAS) all the treatments were significantly different from each other, S@ $60 \mathrm{~kg} \mathrm{ha}^{-1}$ was comparable with S@40 kg ha-1, which recorded a methionine content of 1.34 per cent at 30 DOP (90 DAS) and 1.86 per cent at maturity.

Sulphur nutritional deficiency has previously been reported to have a strong negative effect on cysteine concentration (Macnicol, 1983). In the absence of sulphur, the content of sulphurcontaining amino acids was affected, and the work of Vinod Kumar et al.,(1989) lends support to this. The increase in cysteine and methionine content with sulphur application corroborate with the findings of Dwivedi and Bapat (1998), who found that sulphur fertilization had increased the sulphur-containing amino acids in rapeseed and sunflower. Also, Jarvan et al., (2008) reported an increase in cysteine and 
methionine content in wheat grain due to sulphur fertilization. The increased sulphur content in kernel was significantly correlated with cysteine $(r=0.840 * *)$ and methionine $(r=0.997 * *)$. This supports the findings of the present study.

\section{Protein content}

Sulphur application had a significant influence on protein content (Figure 3), and it showed an increase from control to S @ 60 kg ha-1.Sulphur @ 60 kg ha-1 recorded comparable values with S@ $40 \mathrm{~kg} \mathrm{ha}^{-1}$ at 30 DOP (90 DAS) and maturity. Protein content in the matured kernel ranged between 24.32 per cent (no sulphur) to 26.66 per cent in S@ 60 kg ha-1.

Accumulation of soluble protein in developing seeds during the early stages of seed development is indicative of the synthesis of enzymes and membrane proteins required for the synthesis and accumulation of oil. Improvement in protein content is of paramount importance as it is considered as the building block of the living system. Sulphur is a constituent of the essential amino acid viz., methionine, cysteine, and cystine. It also helps in the conversion of these amino acids into high-quality protein. Sulphur application resulted in increased synthesis of methionine, cysteine, and resulted in increased protein content, which is in accordance with the findings of Tathe (2008). An appropriate structure is essential for protein formation, and sulphur provides disulfide chains and thus helps in increasing the protein content. These results are in support of the findings of Babhulkar et al., (2000).

The results of the present study confirm the observations of Fazli et al., (2010) that the supply of sulphur increased the soluble protein content during seed development. Application of sulphur increased the protein content of groundnut kernel by 36.90 per cent in $\$ @ 60 \mathrm{~kg} \mathrm{ha}^{-1}$ and 32.6 per cent in $\mathrm{S} @ 40$ kg ha-1.

\section{Oil content}

Oil content in the kernel steadily increased with stages of kernel development. The oil content of 20.46 per cent recorded at 15 DOP increased to 37.15 per cent at 30 DOP to 49.18 per cent in the matured kernel. The treatment which received S@ $60 \mathrm{~kg} \mathrm{ha}^{-1}$ recorded the highest oil content at all stages of kernel development (Figure 3 ).

The maximum value of oil content in the kernel was observed with S@ $60 \mathrm{~kg} \mathrm{ha}^{-1}$. The increase in oil content due to sulphur fertilization might be the outcome of better availability of nutrients owing to the favourable environment created by sulphur application. As sulphur is an integral part of oil, the increased availability of sulphur might have favourably influenced the synthesis of essential metabolites responsible for higher oil content.
Sulphur is also known to be involved in the increased conversion of primary fatty acids, several enzymes catalyzing metabolic process which promotes biosynthesis of lipids.

According to Kumar and Yadav (2007), the increase in oil content with an increase in sulphur dose might be due to the involvement of sulphur in the electron transport chain. The strong correlation between kernel sulphur content with oil content $(r$ $=0.959 * *$ ) draws support to the finding. An increase in oil content with sulphur application has earlier been reported by many workers (Mishra and Agarwal (1994); Jena (2006); Noman et al., (2015)).

\section{CONCLUSION}

The study has brought out the response of groundnut ( $\mathrm{CO} 7$ ) to graded levels of sulphur on the yield variation and changes in starch, sugars, cysteine, methionine, protein and oil content with kernel development. Sulphur application at $60 \mathrm{~kg}$ ha-1 remained on par with S @ $40 \mathrm{~kg} \mathrm{ha}^{-1}$ in all of the growth and biochemical parameters, which emphasizes that sulphur fertilization at $40 \mathrm{~kg} \mathrm{ha}^{-1}$ would be adequate for improving the yield and quality of groundnut.

\section{REFERENCES}

A.O. A.C. 1960. Official Methods of Analysis. $18^{\text {th }}$ Edition. Association of Official Agriculture Chemist, Washington, D.C.

Anjum, N.A., Gill, S.S., Umar, S., Ahmad, I., Duarte, A.C. and E. Pereira. 2012. Improving growth and productivity of oleiferous Brassicas under changing environment: Significance of nitrogen and sulphur nutrition, and underlying mechanisms. Science World Journal. http://www.hindawi.com/journals/ tswj/2012/657808/.

Babhulkar, P.S., Dineshkar, W.P. Badole and S.S. Balpande. 2000. Effect of sulphur on yield, quality and nutrient uptake by safflower in Vertisol. Journal of Indian Society of Soil Science., 48(3): 541-543.

CeCeotti, S.P. 1996. Plant nutrient sulphur - A review of nutrient balance, environmental impact and fertilizers. Fertilizer Research., 43: 117-125.

Chaudhary, A.K. 2009. Role of sulphur in oilseeds and its management. Indian Farmers Digest., 42(12): $9-12$.

Dutta, D., Mudi, D.D., Murmu, P. and T. L. Thentu. 2015. Response of Groundnut (Arachis hypogeae) to irrigation schedules, sulphur levels and sources in alluvial zone of west Bengal. Indian Journal of Agronomy., 60(3): 443-449.

Dwivedi, A.K. and P.N. Bapat. 1998. Sulphur-phosphorus interaction on the synthesis of nitrogenous fractions of oil in soyabean. Journal of Indian Society of Soil Science., 46(2): 254-257.

Egesel, C.O., Gal, M.K. and F. Kahriman. 2009. Changes in yield and seed quality traits in rape seed genotypes by sulphur fertilization. European Food Research and Technology., 229(3): 505-513. 
Fahmina, A., Nurul, I., Shamsuddoha, A. T. M., Bhuiyan, M.S.I. and S. Shilpi. 2013. Effect of phosphorus and sulphur on growth and yield of soybean (Glycine max L.). International Journal of Biology., 4: 555-560.

Fazli, I. S., Masoodi, M., Ahmad, S., Jamal, A., Khan, J.S. and M.Z. Abdin. 2010. Intercative effect of sulphur and nitrogen on growth and yield attributes of oilseed crops. J. Plant Nutrition., 33: 1216-1228.

Gaitonde, M.K. 1967. A spectrophotometric method for the direct determination of cysteine in the presence of other naturally occurring amino acids. Journal of Biochemistry., 104: 627-633.

Ghosh, P.K., Mandal, K.G., Bandhyopadhyay, K.K., Hati, K.M., Rao, S. and A.K. Tripathi. 2002. Role of plant nutrient management in oil seed production. Fertilizer News., 47: 67-77.

Giri, U., Kundu, P., Chakraborty, A. and P. Bandyopadhyay. 2011. Effect of sulphur and different irrigation regimes on groundnut. Journal of Crop and Weed., 7(2): 80-83.

Gomez, K.A. and A.A. Gomez. 1984. Statistical procedures for agricultural research (2 ed.). John wiley and sons, New York, 680.

Hodge, J. E. and B. T. Hofreiter. 1962. Determination of reducing sugars and carbohydrates. In: Whistler, R.L.; Wolfrom, M.L., eds. Methods in carbohydrate chemistry. Academic Press, New York, NY, USA. p. 380-394.

Horn, J.M., Jones, D.B. and A.E. Blum. 1946. Colorimetric determination of methionine in proteins and foods. Journal of Biological Chemistry., 166: 313-320.

Jankowski, K., Budzynski, W. and A. Szymanowski. 2008. Effect of sulphur on the quality of winter rape seeds. Journal of Elementology., 13(4): 521 - 534.

Jarvan, M., Edesi, L., Adamson, A., Lukme, L. and A. Akk. 2008. The effect of sulphur fertilization on yield quality of protein and baking quality of winter wheat. Agronomy research., 6(2): 459-469.

Jena, D., Sahoo, R., Sarangi, D.R. and M.V. Singh. 2006. Effect of different sources and levels of sulphur on yield and nutrient uptake by Groundnut-Rice cropping system in an Inceptisol of Orissa. Journal of Indian Society of Soil Science., 54(1): 126-129.

Kumar, A., Sharma, M. and R.K. Mehra. 2008. Effect of phosphorus and sulphur on yield and nutrient uptake by groundnut in inceptisols. Asian Journal of Soil Science., 3(1): 139-141.

Kumar, H. and D.S. Yadav. 2007. Effect of phosphorus and sulphur levels on growth, yield and quality of Indian mustard (Brassica juncea) cultivars. Indian Journal of Agronomy., 52 (2): 154-157.

Lowry, O.H., Rosebrough, N. J., Farr, A.L. and R.J. Randall. 1951. Protein Measurement with Folin Phenol Reagent., Journal of Biology and Chemistry., 193: 265.

Macnicol, P.K. 1983. Differential effect of sulphur deficiency on the composition of the aminoacyl $-t$ RNA and free amino acid pools of the developing pea seed. FEBS letters. 156(1): $55-57$.
Mishra, A. K. and H. P. Agarwal. 1994. Effect of sulphur on growth, yield, protein and oil content of soybean. Journal of Oilseed Research., 11: 99-102.

Nader, R.H. and M.H. Nadia. 2011. Effect of elemental sulphur and partial substitution of $\mathrm{N}$ mineral fertilizer by organic amendments on some properties of slight saline soils. Journal of Applied Sciences Research., 7(12): 2102-2111.

Nasreen Shamima and S. M. Imamul Huq. 2002. Effect of sulphur fertilizer on yield and nutrient uptake of sunflower crop in an Albaquept Soil. Pakistan Journal of Biological Sciences., 5(5): 533-536.

Noman, H.M., Rana, D.S. and K.S. Rana. 2015. Influence of sulphur and zinc levels and zinc solubilizer on productivity, economics and nutrient uptake in groundnut (Arachis hypogaea L.). Indian Journal of Agronomy., 60(2): 301-306.

Patel, G.N., Patel, P.T., Patel, P.H., Patel, D.M. and R. M. Patel. 2009. Yield attributes, yield, quality and uptake of nutrients by summer groundnut (Arachis hypogaea L.) as influenced by sources and levels of sulphur under varying irrigation schedules. Journal of Oilseeds Research., 26(2): 119-122.

Rai, S.K., Deeksha Chark and Rajeev Bharat. 2016. Scenario of oilseed crops across the globe. Plant Archives., 16(1): 125-132.

Ramdevputra, M.V., Akbari, K.N., Sataria, G.S., Vora, V.D. and D.R. Padmani. 2010. Effect of Sulphur application on yield of groundnut and soil fertility under rainfed conditions. Legume Research., 33(2): 143-145.

Randhawa, P.S and C.L. Arora. 2000. Phosphorus sulphur interaction effects on dry matter yield and nutrient uptake by wheat. Journal of Indian Society of Soil Science., 48 (3): 536 - 540.

Saha, B., Saha, S., Saha, R., Hazra, G. C. and B. Mandal. 2015. Influence of $Z n, B$ and $S$ on the yield and quality of groundnut (Arachis Hypogea L.). Legume Research., 38(6): 832-836.

Singh, R.P. 2014. Status paper on oil seed crops. Directorate of Oilseeds Development Government of India, Ministry of Agriculture, Hyderabad.

Singh, S and S.K. Singh. 2016. Use of indigenous sources of sulphur in soils of eastern India for higher crops yield and quality: A review. Agricultural Reviews., 37(2): 117-124.

Somoygi, M. 1952. Notes on sugar determination. Journal of Biological Chemistry., 195(1): 19-23.

Sukhija, P.S., Randhawa, V., Dhillon, K.S. and S.K. Munshi. 1987. The influence of zinc and sulphur deficiency on oil filling in peanut (Arachis hypogaea L.) kernels. Plant and Soil., 103: 261-267.

Tandon, H.L.S. 1995. Sulphur Fertilizer for Indian Agriculture-A Guide book, Second ed. Fertilizer Development and Consultation Organization, New Delhi.

Tathe, A.S. 2008. Response of different levels of sulphur and zinc fertilization on yield and uptake of nutrients by groundnut. Asian Journal of Soil Science., 3(1): 133-136. 
Tomer, T. S., Singh, S., Kumar, S. and S. Tomer. 1997. Response of Indian mustard (Brassica juncea L.) to nitrogen, phosphorus and sulphur fertilization. Indian Journal of Agronomy., 42(1): 148-151.

Upadhaya, H.D., Ortiz, R. and P.J. Bramel. 2003. Genetic Resources and crop evaluation. 50(2): 139 - 148.

Vinod Kumar, Mahendra Singh and Narendra Singh. 1989. Effect of sulphate, phosphate and molybdate application on quality of soyabean grain. Plant Soil., 59: 3-8.
Yadav, R. and D. Singh. 1970. Effect of gypsum on chemical composition, nutrient uptake and yield of groundnut. Journal of Indian Society of Soil Science., 18(1): 183-186. 